\title{
Domestic Slavery, Identity Crisis and Peace Building in Igbo Land: The Case of Atani Community in Anambra Sate, Nigeria
}

\author{
Ikenna Mike Alumona, $\mathrm{PhD}$ \\ Department of Political Science, Chukwuemeka Odumegwu Ojukwu University, Igbariam \\ Jude Odigbo, PhD \\ Department of Political Science, Kwararafa University, Wukari-Nigeria
}

\begin{abstract}
An enduring legacy of the Trans Atlantic slave trade in Atani and most other communities along the banks of the River Niger in Igbo land was the institution of domestic slavery which is presently a defining feature of these communities. Principally nurtured by different forms of discrimination, the institution of domestic slavery has created a sort of identity crisis in these communities. The profound socio-cultural and political impact of the identity crisis has manifested in a constant struggle for supremacy in the sharply divided Atani community. This has hindered peace and community development in the community. This paper examines the identity crisis arising from the institution of domestic slavery and its impact on peace and community development in Atani. We adopted post-structural approach as a theoretical model. A combination of the documentary method and interviews was used to generate data for this study. Data collected were analyzed using qualitative descriptive analysis. The paper argues that certain socio-cultural and traditional practices associated with the institution of domestic slavery have continued to undermine peace in Atani. The paper therefore recommended that ending the prevailing ephemeral peace in Atani requires that governments at all levels, community stakeholders and the traditional rulers should discuss and adopt strategies directed towards abolishing socio-cultural and traditional practices that are detrimental to peace and development in Atani .
\end{abstract}

Keywords: Domestic Slavery, Identity, Crisis, Peace-Building.

DOI: $10.7176 / \mathrm{JCSD} / 57-01$

Publication date:March $31^{\text {st }} 2020$

\section{Introduction}

Atani is one of the fifteen indigenous communities in Ogbaru Local Government Area of Anambra State and also the headquarters of the Local government Area. The town which is located in the basin of the River Niger is popularly known as the food basket of Anambra State. According to oral sources, Atani has a progenitor Afe who migrated from Benin and settled with some persons at Ugwu Aza near Okija town in the present Ihiala Local Government Area. Subsequently the people moved from Ugwu Aza to Ojii and later Abo and then to the present site situated along the banks of the river Niger. Atani like other communities along the banks of the river Niger and its tributaries, participated actively in trading activities along the coast of the river Niger during the colonial era. As a result of the trading activities in Atani over time, a trading factory was opened in Atani in 1884, this was after other trading factories had earlier been opened at Aboh in 1843, Onitsha in 1857, Asaba 1863 and Osomari in 1877( Chukwu 2016). Outside palm produce and other commodities, slaves were also part of the articles of trade during the colonial era. Slaves were bought by wealthy men in Atani community who needed their help in farming and the females who needed their services in their trade. In her discussion of the role of Igbo women in economic transformation in southeastern Nigeria between 1900- 1960, Chukwu (2005,p.56) observed that 'Atani and Ossomari successful female traders could with the consent of their husbands purchase male slaves to accompany them in their trading trips up and down the River Niger. The slaves paddled the trade canoes and helped their mistress sell their trade goods'. The slaves were captives from the hinterland and were exported to different destinations through the banks of the river Niger. Slavery in Nigeria dates back to recorded history and scholars such as Nwokeji (2010), Falola and Njoku (2016), Afigbo (2006) and Ade Ajayi and Uya (2010) have all tried to look at the history and dimensions of slave trade in Nigeria.

Our interest in this paper is not concerned with the history of slavery but with the institution of domestic slavery and the attendant crisis of identity it has caused in Atani community. It is an undeniable fact that human beings at a point in recorded history were articles of trade. As a result of this some persons at one end were sold off through different means and circumstances. At another end people were also bought by others who could afford them. This was the reality of the Atlantic slave trade which also gave rise to the phenomenon of some people being referred to or regarded as slaves in certain communities in Igboland. According to Nzimiro ( 1972,p.26) 'slave (ohu) is part of the status system in some Ibo towns along the Niger'. It is arising from the status system in Igbo land whereby some persons are of slave descent (ohu) and others are free - born (nwadiani) that we can locate the institution of domestic slavery. Domestic slavery is a left over and an inheritance from the iniquitous trade in slaves (Nwabueze,2013). The institution of domestic slavery is perhaps nowhere better described than in the 
following words by Nwabueze (2013,p.41):

'the institution of domestic slavery is an inhuman institution because it regarded 'domestics' (a convenient term) as other than human beings, as mere items of property in the absolute ownership of the master, with power to dispose of or otherwise use or deal with them, as he pleased, which included, as its most atrocious and cruel incident, the use of domestics for the burial of their masters- the number to be so used depended on the standing of the master and the number of domestics he owned. The institution thus rested on, and was nurtured by, discrimination perpetrated against domestics'

It is the discrimination against domestics which Nwabueze captured clearly in the above definition that is behind the identity crisis in Atani community. The connection between domestic slavery and the identity crisis in Atani community is inherently located in the fact that the institution has affected the socio political and cultural context of life in Atani because of the different forms of discriminations perpetrated against the people of slave descent. The discriminations have resulted to the community being divided into two antagonistic groups. One group consists of the people of slave descents and the other group consists of the free born. People from both divides live in the same territorial area yet they do not exist as one community. They perform the same cultural festivals differently. Socially and culturally the community is segmented into two antagonistic groups. It is only in the political context of their existence that they are forced to remain as one by the dictates of modern day organization of government and politics. Even at that, the struggle for political power among the people is somehow affected by the same identity politics of free born and slave descendants. The institution of domestic slavery in Atani has also raised a certain type of citizenship question because the dichotomy between the free born and the slave descents has produced what is described as the 'real or main' Atani indigene. Traditionally, the 'real or main' Atani indigene is defined as somebody who has no link with slavery in his lineage. He or she could be called 'ezigbo onye Atani or Nwa eze aka na abuo'. On the other hand, any individual who is of slave descent is seen as unclean. Different derogatory names have been used to refer to such persons. Such names are 'Onye Taiwan', 'Onye aka ekpe',

Despite the intense emotional reactions generated by the subject matter of domestic slavery in the twenty first century many years after the British government abolished the Atlantic slave trade by the abolition act of 1807, the fact still remains that discriminations arising from domestic slavery still persist not only in Atani community but also in most communities in Igbo land. For instance, Nzimiro(1972) in his famous study of chieftaincy and politics in Oguta, Ossomari, Aboh and Onitsha recorded in great details the various forms of discriminations suffered by those regarded as slaves (ohu) in these Igbo communities. In a related vein, Brown and Lovejoy(eds.)(2010) have also documented the various forms of discrimination associated with domestic slavery in communities such as Nsukka, Nkanu, Nike, and Ezeagu in Enugu State. One clear lesson from the different narratives is that there is in varying degrees some form of stigmatization that is associated with the slave status in Igbo land. Christianity, the abolition of slavery and modern civilization have not significantly altered the stigmatization.

In the Nigerian context, efforts have been made in the direction of eradicating the issue of slavery. The Government of the old eastern region under Dr Nnamdi Azikiwe enacted a law in 1956 titled the Abolition of the Osu system Law. This laudable act by the government then was aimed at removing all forms of disabilities and discriminations against slaves and their descendants. The 1999 Constitution of the Federal Republic of Nigeria also speaks of fundamental human rights which are meant to protect the rights of all Nigerians irrespective of their descent.

Based on this notion, in the past people of slave descent in Atani had taken steps to assert themselves by instituting legal actions against the free born. Yet the truth is that the different court judgements in the various cases have proved abortive in resolving the identity crisis arising from the institution of domestic slavery in Atani as the community is still deeply divided. This has seriously affected peace in the community. Communal clashes between the two groups in the community have in the past led to the infliction of serious injury and destruction of property. In the absence of peace no meaningful development can take place. This is clearly manifest in the near absence of community development efforts in the Atani.

This study is undertaken with a view to deepen our intellectual understanding and knowledge of the subject matter with a view to proffer suggestions that will help to bring lasting peace in Atani community. The study is significant in many respects. It will bring to fore the dynamics of a peculiar form of identity crisis and citizenship question which has remained unresolved. In this sense the findings of this study will be immense benefit to policy makers in the area of community conflict resolution and peace building.

\section{Conceptualizing Identity, Identity Politics and Peace Building}

Identity and identity politics have featured prominently in the literature basically because of its complex nature 
and resurgence in many societies especially in developing societies. In spite of the increasing trend of its manifestation and the attendant consequences, defining identity has remained a difficult task. This can be attributed to the fact that causative factors of identity and identity politics seem to be divergent. These divergent causes are rooted in the contradictory attributes of different societies. As a result, identity is an ambiguous and slippery term and has been used and perhaps overused in many different contexts and for many different purposes, particularly in recent years (Buckingham, 2008). Identity appears as a contradictory idea that can be perceived in different perspectives simultaneously but yet vague.

Studies such as Buckingham, (2008); Elebeke (2010); Wrenn, (2014) have separately explained that identity also implies a relationship with a broader collective or social group of some kind and something uniquely possessed among the groups. Identity is not merely a matter of playful experimentation or "personal growth", it is also about the life-or-death struggles for self-determination that are currently being waged in so many parts of the world (Buckingham, 2008). For Elebeke (2010) identity as a process is located in the core of the individual and yet also in the core of his communal culture, a process which establishes, in fact, the identity of these two identities. However, Zygmunt Bauman insisted that the new prominence that is accorded to identity is a reflection of the fact that it is becoming ever more problematic. In fact, for him, globalization, the decline of the welfare state, increasing social mobility, greater flexibility in employment, insecurity in personal relationships all these developments are contributing to a sense of fragmentation and uncertainty, in which the traditional resources for identity formation are no longer so straightforward or so easily available (Buckingham, 2008).

Thus, by virtue of its complex web of politically salient identities and history of chronic and seemingly intractable conflicts and instability, Nigeria can be rightly described as one of the most deeply divided states in Africa (Osaghae \& Suberu, 2005). It is therefore not surprising that one of the major setbacks to Nigeria's nation building project is identity crisis and identity politics. It has remained endemic and its capacity to continue to permeate urban and local centres, traverse Nigeria's socio-cultural, religious, economic and political milieu underlines the inevitability of instability in the polity.

Although, the concept of identity seems contestable, Wrenn, (2014) is of the view that for proper understanding of the term, attention should be paid to Davis (2010) rubric of three distinct, interrelated components: "personal identities", which are self-ascribed; "collective social identities", which are other-assigned identities and "relational social identities", which consist of voluntary self-identification with social groups, both formal and informal, with varying levels of loyalty to each social group (Wrenn, 2014, p. 504). As can be seen, different groups of people sometimes lay claim to identity especially positive identities in different means which in their views may be recognized as legitimate in the society, but such conviction only attached the issue of identity with social status.

On the other hand, identity politics deals with labelling and presenting a particular ethnic, religious, sociocultural group with certain characteristics to either advance the course of their group or individual aspirations or to degrade it. Thus, it can be seen as social movements which seek to alter the self conceptions and societal conceptions of their participants (Anspach, 1979). Parker (2005) argued that identity politics involves construction and presentation of personae caricatures, even "stereotypes" if you like imagining and portraying particular individuals in terms of certain general traits. He further stated that the second pathological tendency of identity politics arises as healthy grievance against others turns to consuming blame and then to taken-for-granted prejudice. For him, identity is not simply a bad idea that can be calmly corrected or an emotion susceptible to control by adjusting the volume knob because it begins as what may seem a useful weapon in political struggle (Parker, 2005).

Thus, Buckingham, (2008) posited that identity politics refers primarily to activist social movements that have explicitly sought to challenge this process: they have struggled to resist oppressive accounts of their identities constructed by others who hold power over them, and claimed the right to self-determination. In his view, the most obvious aspects of this relate to "race," ethnicity, gender, sexuality, and disability; although the term "identity politics" is also often used in relation to forms of indigenous nationalism, religious groupings (and indeed forms of "fundamentalism"), and so on. According to Buckingham, (2008, p. 7) identity politics thus entails:

a call for the recognition of aspects of identity that have previously been denied, marginalized, or stigmatized. Yet this call is not in the name of some generalized "humanity": it is a claim for identity not in spite of difference, but because of it. As this implies, identity politics is very much about transformation at the level of the group, rather than merely the individual: it is about identification and solidarity. Issues of representation about who has the right to represent, or to speak, and for whom are therefore also crucial here.

Following from the above, it is important to note that several challenges arising from contestable identity, identity politics have huge and sometimes unbearable impact on peace-building in virtually every society. Peacebuilding is a complex process and perhaps demands that in every society that strives towards building peace, all hands must be on deck for the actualization of the process. As can been seen, scholars have remained more consensus on the meaning of peace building in a post conflict or impulsive situation but there seems to be divergent 
opinions on appropriate strategy for peace-building. While peace building is mainly seen as a process of reinvigorating a post conflict society, there is also no consensus that it would preclude slide back into conflict especially when not adequately implemented.

Thus, scholars (Lederach, 1997; Adebo, 2005; Bolarinwa, 2006; Isumonah, 2006; Lotze, De Carvalho \& Kasumba, 2008; Hutton, 2014) have separately posited that peace building is a requisite process for reconstructing a war torn societies, but there is still disparity on the period or time peace building can satisfactorily be done. In fact, experiences on ending wars, conflicts and violent conflicts have shown that conflict does not always end until a completely fresh environment is built from the wrecks of the devastated society, making the societies acceptable and people feeling accepted in it (Nwanegbo \& Odigbo, 2013). Peace building could be seen as a major practical step and planned efforts to (transcend) immediate political difficulties through technical collaboration designed to find solutions to common socio-economic, physical and environmental problems affecting the society. According to Boutros-Ghali (1992) the concept is defined as:

action to identify and support structures which will tend to strengthen and solidify peace in order to avoid a relapse into conflict, rebuilding the institutions and infrastructures of nations form by civil war and strife (and tackling the) deepest causes of conflict: economic despair, social injustice and political oppression (Boutros-Ghali, 1992, p. 8)

Indeed, Peace-building, as Galtung (1975) pointed out, implies something more positive and dynamic than simply creating stability to prevent violent conflict. Rather, it entails building political, social and economic institutions, that revolves around notions of capacity-building, good governance, inclusion, economic opportunity and individual well-being. For him, in order to incorporate this comprehensive understanding of peace, we need to add the concept of development into the peace-building equation. The view of Galtung is that there is huge linkage and relationship between peace and development. In fact, peace-building for him, complements development.

As a result, Fisher, Ludin, Williams, Abdi, Smith, \& Williams (2000) contended that understanding activities that promote long term stability and justice, the peace building processes are central. It also endeavours to create peace, enhance outcomes with due attention to the processes and outcomes. As Galtung (1975) earlier argued peace building is one of the measures of intervening in conflict in order to overcome the contradiction at the root of the conflict formation. He further explained that peace building involves establishing normalized relations between ordinary citizens on both sides of a conflict and includes all efforts to increase "normal", cooperative contacts between opponents. In fact, Lotze, De Carvalho \& Kasumba (2008) posited that sustainable peace processes can be undermined if peace building mechanisms do not develop the capacity of, and give ownership to local agents. Thus, the centrality of peace building process towards resuscitating and reinvigorating unstable societies appears not doubtful. As can be seen, there seems to be greater link between stability, development and the ultimate strategy of empowering man. Peace building is therefore a desideratum and complementary component of development.

\section{Theoretical Perspective.}

The study adopted post-structural approach as a theoretical guide. Post structuralism developed in the late 1960s as a critique or emerging analytical philosophy that seeks to evaluate the structuralist approach. As an offshoot of structuralism, proponents of post-structural approach utilized the approach in the analysis of multi-disciplinary studies. This multi-disciplinary applicability and relevance tends to enhance its analytical utility for understanding the irreversibility of various segment of the entire World. Williams, (2005) explained that post-structural approach remains an influence not only in philosophy, but also in a wider set of subjects, including literature, politics, art, cultural criticisms, history and sociology. For him, this influence is controversial because post-structuralism is often seen as a dissenting position, for example, with respect to the sciences and to established moral values (Williams, 2005, p. 1).

Thus, post-structural theory was postulated and popularized by scholars such as Jacques Derrida, Deleuze, Lyotard, Foucault and Kristeva (Butler, 1990; Radford, 2004; Williams, 2005; Bender, 2011). The central question that poststructuralists pose in their work is precisely how knowledge becomes possible at any particular time under specific historical conditions (Harcourt, 2007). They reject the structuralist notion that structural analysis can help discover general laws with universal character. According to Harcourt, (2007) post-structuralism focuses on: the social distribution of power associated with the construction of knowledge, what has come to be known as the "power/knowledge" critique: How, exactly, do we come to believe what we hold as true? How is it, for instance, that we come to believe a progress narrative of punishment? What institutions and practices shape us to believe in the idea of the "delinquent" or, for that matter, in the idea that we could possibly "rehabilitate" or "correct" that "delinquent"? How have our own disciplinary practices contributed to shaping our beliefs? (Harcourt, 2007, p. 21). 
Essentially, post-structuralism seeks to interrogate conventional knowledge about societies in parts or in totality. It unsettles the things established, and by its own specific methods and ways, it tries to make re-reading on lot of things about the social life and the state (Sayin \& Ates 2012). In fact, Harcourt (2007) asserts that poststructuralism concentrates on the moment when we impose meaning in a space that is no longer characterized by shared social agreement over the structure of meaning. It therefore attempts to explain how it comes about that we fill those gaps in our knowledge and come to hold as true what we do believe and at what distributive cost to society and the contemporary subject (Harcourt, 2007, p. 1).

Following from the above, post-structuralist approach becomes the bedrock for re-examining the prevailing contradictions of institution of domestic slavery and its attendant identity crisis that is presently sweeping through Atani communitiy in Anambra State. Although the nurtured and institutionalization of domestic slavery over several decades in Atani seems to have sustained discriminatory practices among the inhabitants, instigated some sort perennial violence between the beneficiaries of the ill practice and the victims, the failure to engage more proactive measures to abolish such practices has continued to undermined peace in Atani.

Expectedly, it is indeed, incumbent on leaders in a civilized society to strive towards ending such barbaric narratives. This can be achieved through abolishing some socio-cultural practices that degrade human dignity. It should be a strategic approach to unite the people in such a manner that we encourage "we" feeling and collective ownership of the community. In this respect, the increasing manifestation of identity crisis that tends to endanger peace and prosperity of Atani community will be address. It is based on the above assumptions that this study sees post-structural approach as fundamental if not the bedrock of this study.

\section{The Nature and Character of Identity Crisis in Atani}

Generally in Africa, identity politics and its attendant impact on the process of nation building has been identified as the most protracted and challenging problem in the continent (Alumona and Azom 2018). What largely manifest in terms of identity crisis in Africa has always centred on ethnicity and religion but the identity crisis in Atani presents a different picture . The people of Atani both the free born and slave descents are part of the larger Igbo ethnic group thus the crisis could be described as a sub- ethnic identity crisis. The crisis of identity in Atani resolves around the rank and status system in the community. Nzimiro (1972 p.21) writes about the status system in Igboland that classifies people into freemen (nwadiani) and slaves(ohu) in communities such as Oguta, Ossomari, Aboh and Onitsha. Atani community shares some level of cultural affinity and proximity with all of the four towns studied by Nzimiro and as such perfectly fits into his description of the status system.

Historically according to oral sources the genesis of the identity crisis in Atani has been traced to the year 1941 when slave descendants in the community decided to revolt against the age long discrimination against them. The revolt was led by the following slave descendants in the Afor na Isagba family of Abilibose village: Okwude Agunyenwa, Ifeacho Enemuosa, Okolo Nwapa, Onyekwueodilia Akubuo and Ogini Ugunwa who decided to defile the Onyeukwu and Ekwulu shrine by entering the shrines to perform the rites associated with the Igbu title taking ceremony. The Igbu wealth society and the rites associated with it were reserved exclusively for the free born and the slave descendants no matter how wealthy could not take the title. This was the practice for many years before the incident of 1941. By 1941 the British government had firmly taken control of the entire Nigeria with its instruments of governance. Since the free born could not take the laws into their hands by punishing the offenders who committed what was seen as a 'sacrilege', they took the matter to the court. This action polarized the community into two as all the slave descendants in the different families and villages decided to constitute a community of their own rather than continue to suffer disabilities and discriminations. Before this particular incident the slave descendants in Atani were comfortable with the several forms of discriminations prevalent in the community. They were barred from dancing the aligede royal music and from wearing certain things such as ehulu coral beads and the red chieftaincy cap and cloth. They were also barred from marrying a free born .They could not offer sacrifices to all types of shrines and cannot sit on the family throne (ukpo).

The identity crisis in Atani is located in the following areas. First is contestation over land and natural fishing ponds. In the different villages in Atani there are hot contests over lands and fishing ponds between the free born and the slave descendants. The contest over land and fishing ponds resolves around the following factors. First, in some families the slave descendants are no longer comfortable with the portions of land 'given' to them originally by the free born. Secondly, in some other families, the slave descendants are now claiming equal rights with the free born over family lands and fishing ponds. Thirdly, in some families the slave descendants have been excluded completely in the sharing of lands and ponds. The contest over land has usually led to physical fights between the two groups. Apart from the regular physical fights which are usually settled by the Police, there are also many cases in the law court over the struggle for land. The disability suffered by the slave descendants in relation to equal rights with free born over land and fishing ponds has been supported by the law court. For example, Nwabueze (2013,p.13) reports that:

'in a recent 1964 case before the High court in Onitsha, a slave member who was the oldest person in one of the families in Atani claimed to be its head by 
virtue thereof and also to be entitled to exercise the prerogative of the head in relation to the family land and fishing ponds. He and other slave members of the family had claimed an account from the free-born members for fishing the family fish pond without inviting them. The defendants pleaded that as descendants of slave the plaintiff were not entitled to participate as of right in fishing the pond, and this contention was accepted by the court. See Adinnu V, Izukanne, Suit NO.0/19/59 decided on 27 ${ }^{\text {th }}$ July, 1964'

Another of such cases is the one between Christopher Umunna and the Ajada family. Christopher Umunna a descendant of the ex-slaves of Ajada family had erected a bungalow on the land of the Ajada family after several warning by the free born members of the family to stop the building project and he refused. While he was still building the house the free born members of the family took him to court. Eventually when he completed the building and they won the case in the Supreme Court, the court granted them the ownership of the said bungalow. When Christopher Umunna later reconciled with the Ajada family they gave him a different portion of land where his house stands at the moment. Many of such cases abound in Atani. Many cases arising from this issue of right over land and fishing pond are still also in different law courts. Presently unconfirmed sources put the numbers of such land cases at eighteen.

Second is the socio - cultural dimension which borders over wealth title taking, cultural festivals and headship of the family and village unit and the traditional headship of the entire community. Since 1941 when the social discord between the free born and the slave descendants started and families became divided into two- the freeborn and slave descendants, there have been some form of struggle over the headship of the family and village units in Atani. The position is that while the oldest man among the freeborn assumes headship of the family /village and takes the appropriate traditional title, the oldest among the slave descendants also does the same thing. This has always resulted to conflict since the free born usually take steps to prevent the slave descendants from doing such which they not only see an affront but as a sacrilege. In this regard there have been so many petitions to the government and the law enforcement agencies by the free born trying to stop the slave descendants from performing the traditional rites associated with headship of family and village unit. The most recent of such petitions is the one written in December 2016 by Igwe of Atani, Arc. Augustine Azuka Ngoddy. The petition was addressed to the Commissioner of Police in Anambra state against Mr. Emeta Emordi who is the oldest member of the slave descendants in Ajada family. Mr Emeta Emordi was planning to be installed as Ogene of Ajada family. The Ogene title is reserved for the oldest person in the Ajada family. The Igwe's contention as contained in his petition is that Mr Emeta Emordi is aware that the Ajada family 'presently have (sic) a seating Ogene Ajada in the person of Chief Onuorah Otogbolu'.

The struggle over the kingship of Atani is another area where the identity crisis manifests. Before 1941 when the community became polarized into two groups, the kingship of the community had been in abeyance following the death of the king Eze Ogbuefi Otutu who died in 1904(Ezike,2004). The implication of this was that by 1976 when the kingship of the community was revived and it was time for the community to produce a king, a hot contest ensued between the two groups in the community. This led the Anambra state government at that time to set up a commission of inquiry to look into the matter. Following the submission of the report of the panel of inquiry, the government recognized the authority of Chukwudebelu Ezike as the King of the community (Ezike, 2004). This was unacceptable to the group of slave descendants and they refused to recognize his authority. Since the death of Chukwudebelu Ezike in 1989, Atani have had two other kings who are from the same group of the free born. This has continued to tear the community apart since the former slave descendants have refused to recognize the authority of these kings and have always taken actions to undermine their authority.

An aspect of the cultural dimension of the identity crisis has to do with indigenes whose matrineal lineage is linked with slavery. Such individuals also face some level of disabilities and discrimination. Arising from this families take enough time to make enquiries before marriage proposals are concluded particularly if the bride involved is not from a nearby community where they ask easily questions about her lineage.

Thirdly is the political dimension which has to do with the dynamics of party politics. The delineation of electoral constituencies in Atani expectedly did not take into consideration the socio-cultural division among the people. Hence the two electoral wards in the community(i.e Atani ward 1 and 2) are made up of people from both divide. The contestation at this level is seen in the struggle over who represents the community in electoral positions. Party identification during election relatively means nothing to the people. What matters most is the identity of the candidate that is whether he is a free born or a slave descendant? The political feud between the two groups is particularly manifest during the councillorship elections which is meant for the community. Individuals from the Atani who hold political appointments at different levels are seen in the light of which side of the divide that they belong to.

Fourthly another layer of the identity crisis in Atani is located within those who were originally slave descendants but who following the redemption process provided by the free- born had performed the necessary rites associated with the redemption process. This category of persons despite the redemption rites still suffers 
some level of stigmatization. Few cases exist where some families have tried to prevent such persons from enjoying the full rights and privileges accorded to freeborn. Such actions have always been resisted by all those who performed the redemption rites and many who are sympathetic to their cause. A few words on the issue of redemption are necessary at this point. The redemption process is seen as a purification ceremony during which slave descendants are purified and thereafter they are integrated with the free born. The ceremony involves some form of oath taking during which the slave descendant is made to swear an oath of allegiance to the authority of the free born. The redemption process is done in three stages at the family, village and town level. According to oral sources and as confirmed by Nwabueze(2010,p.44) :

'the first person in Atani to redeem himself under the redemption system was $\mathrm{Mr}$ Esimoneze in 1938, reputedly the richest man in atani at that time, an employee of the United Africa company(UAC) from where he made his money. After redeeming himself as a domestic of the Odunze family ('attachee', as they are sometimes called) whose ancestor bought him in the 1890's, he traced his original home to Agenegbode (presently in Delta state of Nigeria), then returned and built a house there. As, however, he could not adjust to life in Agenebode after being uprooted from it as a youngster, he came back to Atani, built a house and became more or less fully integrated with the free-born indigenes, took the Igbu wealth title(previously forbidden to him) and married a free born girl.

The conditions for allowing a slave descendent to redeem himself varies across the different families but the identified stringent conditions ones include: total exclusion from enjoying family land and fishing pond and denial of the right to assume headship of the family. It is reported that Atani remains the only community in Ogbaru where there is the opportunity for bought slaves to redeem themselves and thereafter integrate with the free- born.

Taking together the different manifestation of disabilities and discriminations that define the character of the domestic slavery in Atani raises some fundamental questions such as: why has the government not found a permanent solution to the problem? Have efforts been made by Atani indigenes to solve the problem generated by the identity crisis in their community? If yes, why have such efforts not yield the desired results? Obi-ani (2010, p.320) has provided us a useful insight into why the problems associated with domestic slavery still persists in Igboland. He puts it thus:

in southern Nigeria the abolition of domestic slavery was sudden, autocratic and somewhat vague. There was no consultation with the slave owners on the modalities of abolition, whether compensation would be paid, and the status of liberated slaves in their communities was not clear. The colonial masters did little to educate the people on the gains of the liberation of their slaves or their reintegration into the larger society. Rather than solving the problem of slavery in Igboland, the British compounded it, setting two classes at war out of ignorance. In the ensuing conflict the British acted as umpires of questionable morals. While they insisted that freedom must be extended to the domestic slaves, they denied the fruits of freedom to the freeborn.

It is important to point out the role of Christianity and modernity which came with colonialism in instigating the identity crisis in Atani. Before 1941 when the old system of discrimination witnessed a major revolt by the slave descendants, the entire community had lived in peace. But with time, the impact of Christianity and modernization started to permeate the community that the slave descendants could no longer understand and tolerate the different forms of discriminations existing in the society hence the revolt which since then has created a major social discord in the community.

\section{The Domestic Slave and Free born dichotomy in Atani: the Quest for Peace Building and Conflict Resolution}

The dichotomy between the free born and slave descendants in Atani has continued to hinder peace and community development. Time and resources that could have used to promote development have been spent by both groups in court litigations. Peaceful coexistence has been difficult in the face of the perennial conflict mainly because both groups live in the same territory area unlike what we find in some communities in Ogbaru such as Ossomari and Odekpe where the free born and slave descendants are territorial separated. The impact of the identity crisis on the psychology of the people cannot be ignored as vengeance, hatred and animosity have over time been built up among people. The challenge today is how to create a one united and peaceful Atani community devoid of all forms of discriminations.

In the past efforts have been made at resolving the conflict and peace building in the community. It was reported that since the 1990's Prof Ben Nwabueze has made spirited efforts at reconciling the two groups. Several meetings have been held on the matter. Discussion about integration always broke down over disagreements on the modalities for integration. The option of redemption which was the popular option then and which some 
prominent indigenes had followed was vehemently opposed by the people of slave descent. Within the same period, J.C.Okeke, an indigene who left Atani to settle at Nnewi over the same problem of identity had also tried to settle the crisis without success. His plan of providing as many cows as possible for a common and general integration was opposed by the free born. The objection by the free born is that a common integration will not provide solution to the problem of social relations and coexistence at the family level. In 2009 Ben Nwabueze started another integration and peace process that was meant to integrate all indigenes into one community irrespective of descent. As part of the integration, he created a governing council for the entire community with equal membership from both sides. A youth council, town union, women council and eleven different committees were also created. These institutions for integration were initially widely accepted and worked for sometime before the entire process broke down over the issue of succession to the headship of the family or village, and the right to hold and minister to its ofo - the spiritual symbol of unity and authority. As contained in the peace and integration document prepared by Ben Nwabueze in 2009, 'succession to the headship of a family or village should be by seniority of age, irrespective of descent, provided that this will not involve the current head of the original family or village having to step down for a person in the other group older than himself; when he dies, succession by seniority of age, irrespective of descent will become fully operative without restriction'. As pointed out, it was at this point that the entire process broke down and the community once again after one year of trying to stay together as one community returned back to the status quo. The interviews we conducted with people from both sides reveals that they were are not really happy with the succession plan. The grouse of the free born lies in the fact the plan will expose them to a situation where a former slave descendant will now administer their ancestral ofo in the future. On the other hand, the slave descendants feel that accepting the condition is an acceptance of the status of second class citizens which is attached with slavery. Still disturbed about the identity crisis in Atani and other communities in Ogbaru Local government, the Ogbaru traditional Rulers Council in October 2018, had set up a committee on peace and integration in the entire Ogbaru local government. With equal representation from both sides in each of the different towns in Ogbaru, the committee is charged with the duty of writing a proposal for integration that will be used in the entire local government. It is hoped that the proposal of the committee will be acceptable to both sides of the conflict so the matter will be resolved amicably.

\section{Conclusion.}

This paper has basically tried to examine the character and dynamics of the identity crisis in Atani community. The paper out that the character of identity politics which is basically defined by the dichotomy between descents of ex slaves and free born has in many ways adversely affected the socio cultural and political organization of life in the community. The stigmatization and discrimination that is associated domestic slavery has seriously undermined peaceful coexistence and community development in the community. The paper recommends that it is time for government to step in and explore a concrete means of resolving the conflict.

\section{References}

Ade- Ajayi, J. F \& Uya, O. (eds.) (2010). Slavery and Slave Trade in Nigeria: From Earliest Times to the $19^{\text {th }}$ Century. Ibadan: Safari Books.

Adebo, T. (2005). Post-conflict peace-building and prospects for democracy with reference to Africa. Uppsala: Life and Peace Institute.

Afigbo, A.E.(2006). The Abolition of the Slave trade in Southeastern Nigeria,1885- 1950. Rochester: University of Rochester Press.

Alfred, C. (2016). Peace and conflict studies: Conceptual explanations and typologies. In C.J. Nwanegbo \& S.A. Banke (Eds.), Peace and conflict studies: An introduction (pp. 1-20). Makurdi: Traeces Publishing Company

Anspach, R. R. (1979). "From stigma to identity politics: Political activism among the physically disabled and former mental patients". Social Science and Medicine, 13 (4) 765-73.

Bender, J. (2011). For all things must fail: A post structural approach to the book of mormon. Journal of Mormon Thought, 45 (3), 138-149.

Bolarinwa, J.O. (2006). Introduction to peace studies. National Open University Teaching Module, Lagos: NOUN.

Boutros-Ghali, B. (1992). An agenda for peace: Preventive diplomacy, peacemaking and peacekeeping. A/47/277-S/24111. Geneva, United Nations.

Buckingham, D. (2008). "Introducing identity" youth, identity and digital media. In D. Buckingham (Ed.), Digital media and learning (pp. 1-24). Cambridge: The MIT Press.

Butler, J. (1990). Gender Trouble: Feminism and the Subversion of Identity. New York: Routledge.

Chukwu, G. (2005) Igbo Women and Economic Transformation in South-eastern Nigeria 1900-1960. New York: Routledge

Elebeke, E. (2010). Identify crisis: Who really are Nigerians? Identity management crisis at CTO. Avalaible Online: http://urozgan.org/fa-af/ide/crisis/article/939/

Ezike, O.(2004). Kingship Institution in Atani. Unpublished B.Sc Project Submitted to the Department of History 
and International Studies, Nnnamdi Azikiwe University, Awka, Anambra State.

Fisher, S., Ludin, J., Williams, S., Abdi, D., Smith, R. \& Williams, S. (2000). Working with conflict skills and strategies for action. London: Zed Books.

Galtung, J. (1975). Three Approaches to Peace: Peacekeeping, Peacemaking and Peacebuilding. In J. Galtung (ed.), Peace, war and defence: Essays in peace research. (pp. 24-52). Copenhagen: Christian Elders.

Harcourt, B. (2007). An answer to the question: What is post-structuralism? University of Chicago Public Law \& Legal Theory Working Paper, No. 156

Hutton, L. (2014). South Sudan: From fragility at independence to a crisis of sovereignty. Hague: Netherlands Institute of International Relations Clingendael.

Isumonah, V. A. (2006). Problems of Peacemaking and Peacekeeping. In I. O. Albert (ed.), Perspectives on peace and conflict in Africa, Essays in honour of General Abdulsalami A. Abubakar. (pp. 17-33). Ibadan: Peace and Conflict Studies Programme Institute of African Studies.

Lederach, J. (1997). Building peace and sustainable reconciliation in divided societies. Washington D.C.: United States Institute of Peace.

Nwabueze, B (2009). Peace and Integration in Atani. Unpublished paper.

Nwabueze, B (2013). Ben Nwabueze: His Life, Works and Times - An Autobiography. Vol.1. Ibadan: Gold Press Limited.

Nzimiro, I.(1972). Studies in Ibo Political Systems: Chieftaincy and Politics in Four Niger States. California: University of California Press

Nwanegbo, J \& Odigbo, J. (2013). Post-independence peace-building in South Sudan: Looking beyond ephemeral peace. International Journal of Social Science Tomorrow, 2 (1), 1-10.

Obi- ani, P (2010). The Stigmatization of Descendants of Slaves in Igboland. In Brown, C.A and Lovejoy, P.E (eds.) Repercussions of the Altantic Slaves Trade: the interior of the Bight of Biafra and the African Diaspora. Africa World Press Inc.

Osaghae, E. \& Suberu, T. (2005). A history of identities, violence, and stability in Nigeria. Oxford: Centre for Research on Inequality, Human Security and Ethnicity (CRISE), Working Paper No. 6.

Parker, R. D. (2005). Five theses on identity politics. Harvard Journal of Law \& Public Policy, 29 (1), 53-59.

Radford, G. P. (2004). Structuralism, poststructuralism and library: De Saussure and Foucault. Journal of Documentation, 61 (1), 60-78.

Reardon, B.A. (1988). Comprehensive peace education. New York: Teachers College Press.

Sayin, Y. \& Ates, D. (2012). Poststructuralism and the analysis of international relations. Alternatives Turkish Journal of International Relations, 11 (2), 13-25.

Williams, J. (2005). Understanding poststructuralism. Chesham: Acumen Publishing Limited.

Wrenn, M. (2014). Identity, identity politics and neoliberalism. Panoeconomicus, 4 (1), 503-515. 